\title{
Our experience with dermal substitute Nevelia in the treatment of severely burned patients
}

\author{
๑ Hakan Yiğitbaş, M.D., ${ }^{\circledR}$ Erkan Yavuz, M.D., ${ }^{1}$ Evrim Beken Özdemir, M.D., ${ }^{1} \odot$ Önder Önen, M.D., ${ }^{1}$

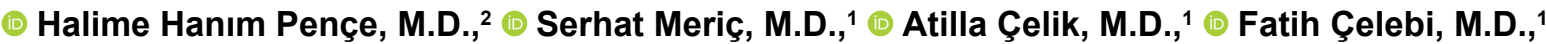 \\ (1) Ahmet Çınar Yastı, M.D., ${ }^{3} \oplus$ Tansel Sapmaz, M.D., ${ }^{4}$ ๑ Aydın Zilan, M.D., ${ }^{1} \oplus$ Mustafa Turan, M.D. ${ }^{1}$
}

\begin{abstract}
'Department of General Surgery, Health Sciences University Bağcılar Training and Research Hospital, İstanbul-Turkey ${ }^{2}$ Department of Biochemistry, Health Sciences University Faculty of Medicine, İstanbul-Turkey ${ }^{3}$ Department of General Surgery, Health Sciences University Ankara Numune Training and Research Hospital, Ankara-Turkey ${ }^{4}$ Department of Histology and Embryology, Health Sciences University Faculty of Medicine, İstanbul-Turkey
\end{abstract}

\begin{abstract}
BACKGROUND: This research aims to retrospectively evaluate the effectiveness and safety of dermal substitute (DS), Nevelia ${ }^{\circledR}$, for the treatment of severely burned patients.

METHODS: Twenty severely burned patients were enrolled in this study between May 2017 and May 2018. After escharotomy of the wound, the treatment protocol was applied following a two-step procedure -DS implantation followed by split-thickness skin graft (STSG) application. Need for surgery, complications, hospitalisation duration and overall survival were analysed.

RESULTS: Mean age was 40.1 \pm 4 (18-86) years old; female/male: 5/15. Mean burn surface area was $50.1 \% \pm 2$ (25-96). Two patients died under hospital treatment due to the severity of their burn trauma and comorbidities. For the rest of the cases, STSG was performed after $\mathrm{Nevelia}^{\circledR}$ at mean 21.2 days. No complications due to Nevelia ${ }^{\circledR}$ were detected. The patients were discharged with a mean total recovery of $55.2 \pm 4$ days.
\end{abstract}

CONCLUSION: This study showed that Nevelia ${ }^{\circledR}$ can be used safely and effectively in severely burned patients with low complication rates and short hospital stay.

Keywords: Dermal substitute; eschar management; major burn.

\section{INTRODUCTION}

The principle of care in managing severely burned patients is primarily focused on survival. The main issues in the first hours are resuscitation and haemodynamics. After 48 hours, septic problems and eschar management eventually become a critical issue. The insufficiency of skin graft donor sites in severely burned patients is one of the major problems in the management of these patients.

Dermal substitutes (DS) are becoming an important part of burn care with an increasing interest. In the acute phase of burn treatment, the use of DS ameliorates functional and aesthetic long-term results. DS are bio-matrices that perform the functions of the cutaneous dermal layer, including protecting the subcutaneous tissue from physical factors, acting as a barrier against infections and reducing scarring. DS, which act like matrices or scaffold and support tissue buildup, boost wound healing consequently. ${ }^{[1,2]}$ The structure of DS provides flexibility and better scar tissue formation. In both acute and chronic stages, DS has a large part in healing fullthickness skin defects ${ }^{[3]}$ and advanced scar quality. ${ }^{[4]}$

Cite this article as: Yiğitbaş H, Yavuz E, Beken Özdemir E, Önen Ö, Pençe HH, Meriç S, et al. Our experience with dermal substitute Nevelia in the treatment of severely burned patients. Ulus Travma Acil Cerrahi Derg 2019;25:520-526.

Address for correspondence: Hakan Yiğitbaş, M.D.

Sağlık Bilimleri Üniversitesi Bağcılar Eğitim ve Araştırma Hastanesi, Genel Cerrahi Kliniği, İstanbul, Turkey

Tel: +90 212 - 4404000 / 3389 E-mail: drhyigitbas@yahoo.com.tr

Ulus Travma Acil Cerrahi Derg 2019;25(5):520-526 DOI: 10.14744/tjtes.2019.24358 Submitted: 06.04.2019 Accepted: 05.08.2019 Online: 23.08 .2019

Copyright 2019 Turkish Association of Trauma and Emergency Surgery 
Nevelia ${ }^{\circledR}$ (Symatese Aesthetics, Lyon, France) is made from specific native collagen with a large fibrous proportion to preserve cell adhesion signals and mechanical structure to support regeneration. In vitro test demonstrate an optimised colonisation as fibroblasts recognise collagen fibres. Nevelia ${ }^{\circledR}$ is indicated for dermal regeneration in cases involving skin loss, particularly in burns and trauma. This bi-layer matrix is usually used in combination with a thin split-thickness skin graft (STSG) to recreate skin resembling the normal one in terms of function and appearance. This research describes our experience in using $\mathrm{Nevelia}^{\circledR}$ for the treatment of severely burned patients.

\section{MATERIALS AND METHODS}

This retrospective case series study was approved by the Health Sciences University, Bağcılar Education and Research Hospitals' Ethics Committee. This study included patients who were admitted to a burn care unit with severe fullthickness burn wounds [Total Body Surface Area (TBSA) 225\%] between May 2017 and May 2018. Their need for surgery, complications, hospitalisation duration and overall survival were analysed. TBSA percentage and TBSA with Nevelia ${ }^{\circledR}$ surface were measured using the Lund and Browder chart. ${ }^{[5]}$

Burn patients were categorised according to a specific clinical burn management protocol designed to stabilise them within 48 to 72 hours. Later, using the SPY ${ }^{\circledR}$ Infrared Fluo- rescence Imaging System (Novodaq, Stryker, US), burn depth was measured. According to the patient's clinical state and tolerance, viable and healthy dermis were protected. Chemical eschar debridement and reepithelisation procedures were performed. In burn areas that were not too deep, self-healing procedures were followed. In areas with a third-degree burn, early eschar excision protocol was used. Then, Nevelia ${ }^{\circledR}$ was applied to the escharotomy areas.

Nevelia ${ }^{\circledR}$ was applied on the burn area using ApposeTM Single-Use Skin Stapler (Medtronic, MN, USA) and was dressed with antimicrobial materials. The dressing was changed every two days. Integration of the Nevelia ${ }^{\circledR}$ to the tissues was observed during this time.

The subsequent delamination of $\mathrm{Nevelia}^{\circledR}$ (silicone leaf removal) and the timing of split-thickness skin graft application were determined on a case-to-case basis according to the availability and physiological well-being of the subject. Re-harvesting from the same donor site was necessary for some patients. Therefore, the state of re-epithelialization of the skin graft donor site was very important for them. Once delaminated, the surface of the neodermis was refreshed by dermabrasion before meshed STSG was applied and the dressing was performed.

The thickness of harvest and mesh ratio of the STSG was determined clinically on each occasion by donor site availability, and the need for the second harvest from the same
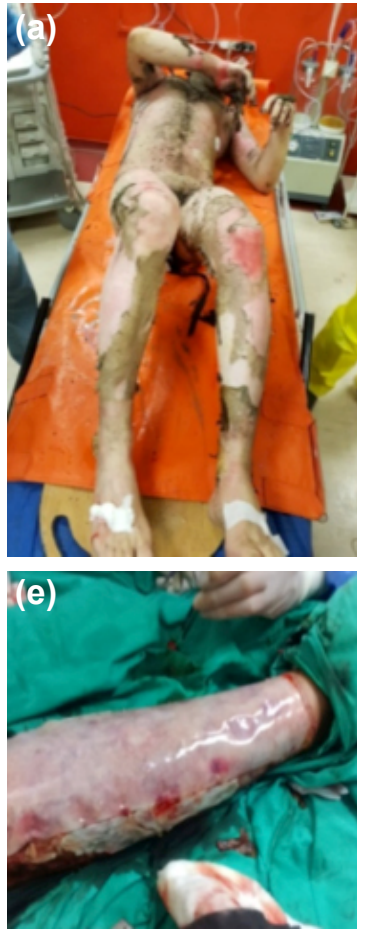
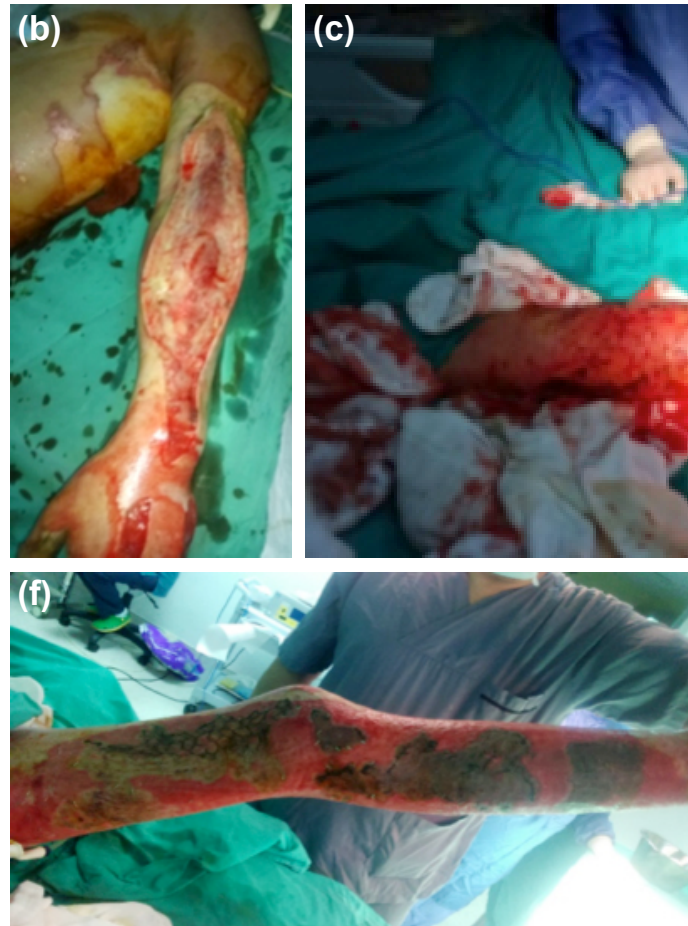

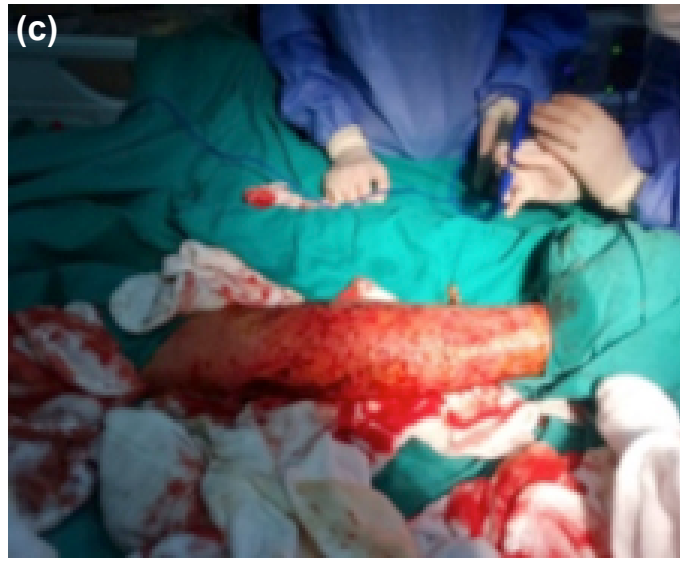

(g)

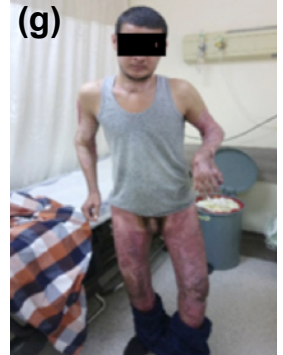

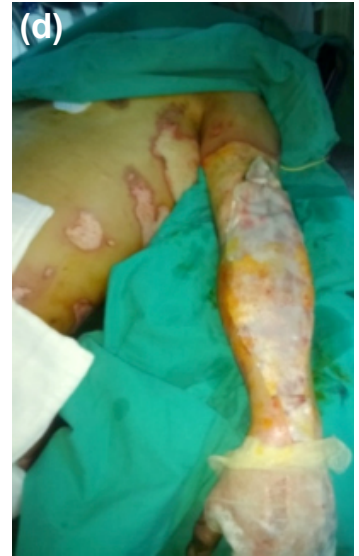

(h)

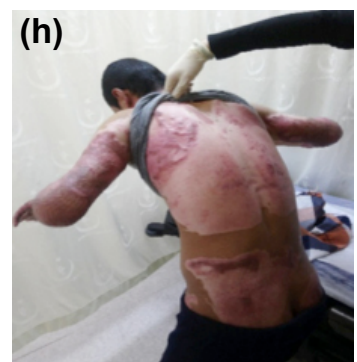

Figure 1. Case 1: 23 years old man (Subject 9), burned on 90\% of his TBSA following a work accident. (a) The right and left limbs and the trunk were burned and underwent fascial excision. (b, c) Fasciotomy lines. No residual dermal element was left. (d, e) Nevelia ${ }^{\circledR}$ cut to shape and applied with staples. (f) Vascular invasion and collagen deposition complete by Day 20. (g, h) The autograft appearance 90 days after application over the integrated $\mathrm{Nevelia}^{\circledR}$ neo-dermis. 

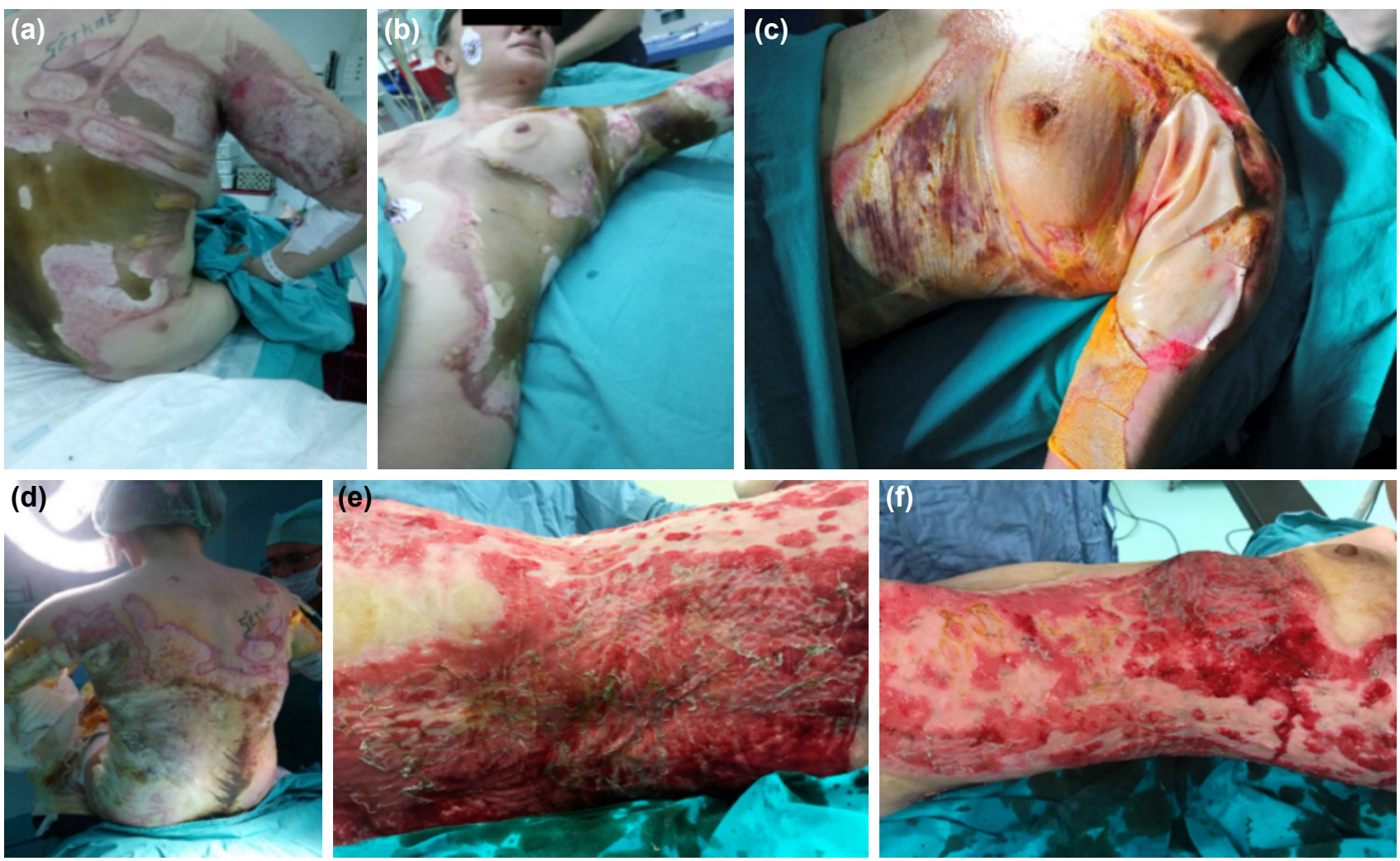

Figure 2. Case 2: 28 years old woman (Subject 19), burned on $60 \%$ of her TBSA following a house accident. (a, b) The right and left limbs and the trunk were burned and underwent fasciotomy and tangential excision. (c, d) Nevelia ${ }^{\circledR}$ cut to shape and applied with staples. Vascular invasion and collagen deposition complete by Day 20. (e, f) The autograft appearance 6 and 12 days respectively after grafting.

donor areas was anticipated. In this study, all grafts applied over Nevelia ${ }^{\circledR}$ were either applied as fenestrated sheet graft (over the dorsum of hands) or meshed I,5-3, at all other sites. Skin grafts were dressed according to our previous standard of care, typically with paraffin gauze overlaid with saline and antibacterial-soaked gauze secured with crepe bandages. Dressings were changed with graft check at four days and then twice weekly until completely healed.

Photographic records were taken at every intervention (Figs. I, 2). The punch biopsy specimens of representative areas were taken at various intervals for culture. All subjects received standard physiotherapy scar treatment, which included compression garment therapy.

\section{RESULTS}

\section{Patient Characteristics}

Twenty adult patients aged between 18 and 86 years old (mean age 40.1 \pm 4 ) shown in Table I were enrolled in this study. Five out of 20 patients were female. Burn incidents had occurred mostly at work and home $(45 \%$ and $40 \%$, respectively). Seventy percent of the patients were in a closed area and were exposed to inhalation injuries. Full-thickness burn wounds covered $25 \%-96 \%$ of TBSA with a mean surface of $50.1 \% \pm 2 \%$. The mean surface receiving Nevelia ${ }^{\circledR}$ was $8.25 \% \pm 1 \%$ of TBSA (on third-degree burn area).

\section{Nevelia ${ }^{\circledR}$ application}

The colonisation of $\mathrm{Nevelia}^{\circledR}$ and mean duration time for the STSG acceptance was $21.2 \pm 3$ days. Other than two integration failure, no adverse event or complications related to the use of Nevelia ${ }^{\circledR}$ were seen. Patients were discharged with a mean recovery of $55.2 \pm 4$ days (Table 2 ).

Among the 20 patients, failure was seen in two patients who had DS Nevelia ${ }^{\circledR}$. These two cases had burn wound in $92 \%$ and $96 \%$ of their TBSA with multiple comorbidities. The clinical status of these two patients was critical, and they died from their injuries. Their wound healing was poor, probably because of multiorgan insufficiency.

\section{DISCUSSION}

Patients with severe full-thickness burn wounds require artificial materials due to the deprivation of sufficient donor tissue. Identifying efficient, safe and cost-effective skeleton materials can be stressful. Autologous skin graft is the most preferred material in burn wound coverage; however, especially in extensive full-thickness burn wounds, having limited donor sites can complicate the process. Another distressing point is the presence of donor tissue morbidities regarding having additional wounds and scars. This issue required various skin substitutes for the treatment of acute full-thickness burn wounds. ${ }^{[6]}$ 
Table I. Subject demographics and mechanisms of burn injury

\begin{tabular}{|c|c|c|c|c|c|c|}
\hline $\begin{array}{l}\text { Subject } \\
\text { No. }\end{array}$ & Age & Gender & Burned areas & Mechanisms of burn injury & $\begin{array}{l}\% \text { TBSA } \\
\text { burn }\end{array}$ & $\begin{array}{l}\text { DS areal } \\
\text { TBSA (\%) }\end{array}$ \\
\hline I & 68 & Male & Lower limbs & $\begin{array}{l}\text { The explosion of Liquid Petroleum Gas } \\
\qquad \begin{array}{l}\text { (LPG) bottle. Enclosed space, } \\
\text { inhalation injury. }\end{array}\end{array}$ & 50 & 8 \\
\hline 2 & 18 & Male & Lower limbs & Working place fire with petrol indoors. & 25 & 3 \\
\hline 3 & 64 & Male & Lower limbs and trunk & $\begin{array}{l}\text { Working place fire with petrol indoors. } \\
\text { Enclosed space, inhalation injury. }\end{array}$ & 50 & 7 \\
\hline 4 & 39 & Male & $\begin{array}{l}\text { Upper limbs, lower } \\
\text { limbs and trunk }\end{array}$ & $\begin{array}{l}\text { Working place fire. } \\
\text { Enclosed space, inhalation injury. }\end{array}$ & 40 & 5 \\
\hline 5 & 32 & Female & $\begin{array}{l}\text { Head, upper limbs, } \\
\text { lower limbs and trunk }\end{array}$ & $\begin{array}{l}\text { Heroin intoxication. House fire started } \\
\text { by cigarette falling into the carpet. } \\
\text { Enclosed space, inhalation injury. }\end{array}$ & 92 & 4 \\
\hline 6 & 86 & Female & Lower limbs and trunk & $\begin{array}{l}\text { House fire secondary to LPG oven. } \\
\text { Enclosed space, inhalation injury. }\end{array}$ & 40 & 6 \\
\hline 7 & 41 & Male & Lower limbs and trunk & $\begin{array}{l}\text { Working place fire. } \\
\text { Enclosed space, inhalation injury. }\end{array}$ & 40 & 5 \\
\hline 8 & 62 & Male & Upper limbs and trunk & Garden fire explosion. & 30 & 10 \\
\hline 9 & 23 & Male & Upper/lower limbs, trunk & $\begin{array}{l}\text { Working place fire with the explosion } \\
\text { of the water boiler. }\end{array}$ & 90 & 23 \\
\hline 10 & 38 & Male & Upper/lower limbs, trunk & $\begin{array}{l}\text { Self-immolation with petrol indoors. } \\
\text { Enclosed space, inhalation injury. }\end{array}$ & 96 & 18 \\
\hline II & 25 & Male & Upper/lower limbs & $\begin{array}{l}\text { Working place fire with gasoline and motor oil. } \\
\text { Enclosed space, inhalation injury. }\end{array}$ & 40 & 4 \\
\hline 12 & 20 & Male & $\begin{array}{l}\text { Upper/lower limbs, } \\
\text { trunk }\end{array}$ & $\begin{array}{l}\text { Working place fire with gasoline. } \\
\text { Enclosed space, inhalation injury. }\end{array}$ & 75 & 10 \\
\hline 13 & 25 & Male & Lower limbs & $\begin{array}{l}\text { Bonzai intoxication. House fire started by cigarette } \\
\text { falling into the carpet. Enclosed space, inhalation injury. }\end{array}$ & 32 & 16 \\
\hline 14 & 40 & Male & Upper/lower limbs, trunk & Working place burn with high voltage electricity. & 32 & 6 \\
\hline 15 & 32 & Male & Upper limb, trunk & $\begin{array}{l}\text { Bonzai intoxication. House fire started by } \\
\text { cigarette falling into gasoline. }\end{array}$ & 33 & 8 \\
\hline 16 & 23 & Female & Upper limb, trunk & House fire secondary to deodorant gas. & 30 & 6 \\
\hline 17 & 32 & Male & Upper/lower limbs & $\begin{array}{l}\text { Working place fire secondary to the electrical fault. } \\
\text { Enclosed space, inhalation injury. }\end{array}$ & 40 & 4 \\
\hline 18 & 45 & Male & Upper limb, trunk & $\begin{array}{l}\text { Alcohol intoxication. House fire started by cigarette } \\
\text { falling into the carpet. Enclosed space, inhalation injury }\end{array}$ & 41 & 7 \\
\hline 19 & 28 & Female & Upper limb, trunk & $\begin{array}{l}\text { Alcohol intoxication. House fire started by cigarette } \\
\text { falling into the carpet. Enclosed space, inhalation injury }\end{array}$ & 60 & 9 \\
\hline 20 & 53 & Female & $\begin{array}{l}\text { Upper/lower } \\
\text { limbs, trunk }\end{array}$ & $\begin{array}{l}\text { Suicide attempt by opening the home natural gas. } \\
\text { Home fire secondary to electrical spark. } \\
\text { Enclosed space, inhalation injury. }\end{array}$ & 45 & 6 \\
\hline
\end{tabular}

At present, there are numerous DS products available commercially. Most of these products have been extensively tested and examined in both pre-clinical and clinical settings. ${ }^{[7-10]}$ In the last I-year period, we have applied $\mathrm{Nevelia}^{\circledR}$ to several escharotomy areas of some of our severely burned patients.
Many of the present biocompatible DS can mimic the basic properties of the extracellular matrix in human skin by providing some structural integrity, elasticity and vascular bed. It reduces evaporative water loss, and the exudation of proteinrich fluids prevents wound desiccation and suppress micro- 
Table 2. The number of days for the DS integration, tpe length of stay, adverse events suffered by each subject, classified as those related to the burn injury and its pathophysiological evolution, and those related to the DS

\begin{tabular}{|c|c|c|c|c|c|c|}
\hline $\begin{array}{l}\text { Subject } \\
\text { No. }\end{array}$ & $\begin{array}{l}\text { Total } \\
\text { days of } \\
\text { DS to } \\
\text { integrate }\end{array}$ & $\begin{array}{l}\text { Failure } \\
\text { of DS } \\
\text { integration }\end{array}$ & $\begin{array}{l}\text { Comorbidities/ } \\
\text { clinically } \\
\text { relevant } \\
\text { situation }\end{array}$ & Burn-related AE & $\begin{array}{l}\text { Length } \\
\text { of stay } \\
\text { (days) }\end{array}$ & Result \\
\hline I & 21 & - & Hypertension & $\begin{array}{l}\text { Lower airway inhalation } \\
\text { injuries, Pneumonia }\end{array}$ & 83 & Discharged with recovery \\
\hline 2 & 22 & - & - & - & 28 & Discharged with recovery \\
\hline 3 & 20 & - & Hypertension & - & 66 & Discharged with recovery \\
\hline 4 & 21 & - & - & - & 46 & Discharged with recovery \\
\hline 5 & 21 & $\begin{array}{l}\text { Failure of DS } \\
\text { integration in } \\
\text { one of six areas. }\end{array}$ & Drug abuse & $\begin{array}{l}\text { Significant lower airway inhalation injuries } \\
\text { Pneumonia } \\
\text { Pseudomonas, Acinetobacter, candida } \\
\text { Acute renal injury requiring dialysis } \\
\text { ileus, abdominal compartment syndrome, }\end{array}$ & 23 & Death \\
\hline 6 & 21 & - & $\begin{array}{l}\text { Alzheimer, } \\
\text { hypertension }\end{array}$ & $\begin{array}{c}\text { Pneumonia } \\
\text { Pseudomonas, Acinetobacter in the } \\
\text { wound, candida in the blood } \\
\text { Small graft breakdowns on the trunk and lower limb }\end{array}$ & 125 & Discharged with recovery \\
\hline 7 & 20 & - & - & - & 64 & Discharged with recovery \\
\hline 8 & 23 & - & $\begin{array}{l}\text { Kidney transplant } \\
\text { (5 years ago })\end{array}$ & $\begin{array}{l}\text { Lower airway inhalation injuries } \\
\text { Significant wound healing delay } \\
\text { Pseudomonas, acinetobacter in the wound, }\end{array}$ & 72 & Discharged with recovery \\
\hline 9 & 23 & - & - & $\begin{array}{l}\text { Significant lower airway inhalation injuries, } \\
\text { Pneumonia, ventilation support. } \\
\text { lleus, abdominal compartment syndrome, } \\
\text { Pseudomonas, Acinetobacter in the wound }\end{array}$ & 98 & Discharged with recovery \\
\hline 10 & 16 & $\begin{array}{l}\text { Failure of DS } \\
\text { integration in } \\
\text { one of six areas. }\end{array}$ & . & $\begin{array}{l}\text { Significant lower airway inhalation injuries, } \\
\text { pneumonia, ventilation support. } \\
\text { Abdominal compartment syndrome, } \\
\text { open abdomen by Bogota bag Acute } \\
\text { renal injury requiring dialysis }\end{array}$ & 16 & Death \\
\hline II & 23 & - & - & $\begin{array}{l}\text { Significant lower airway inhalation } \\
\text { injuries, pneumonia. }\end{array}$ & 35 & Discharged with recovery \\
\hline 12 & 21 & - & - & - & 75 & Discharged with recovery \\
\hline 13 & 22 & - & Drug abuse & - & 62 & Discharged with recovery \\
\hline 14 & 20 & - & - & - & 45 & Discharged with recovery \\
\hline 15 & 21 & - & - & - & 43 & Discharged with recovery \\
\hline 16 & 20 & - & - & - & 32 & Discharged with recovery \\
\hline 17 & 21 & - & - & - & 62 & Discharged with recovery \\
\hline 18 & 23 & - & $\begin{array}{l}\text { Alcoholism. } \\
\text { Child a cirrhosis } \\
\text { due to alcohol. }\end{array}$ & Lower airway inhalation injuries & 45 & Discharged with recovery \\
\hline 19 & 23 & - & $\begin{array}{l}\text { Drug abuse } \\
\text { and alcoholism. }\end{array}$ & - & 50 & Discharged with recovery \\
\hline 20 & 22 & - & Alcoholism & $\begin{array}{l}\text { Lower airway inhalation injuries, pneumonia, } \\
\text { she needed mechanical ventilation support. }\end{array}$ & 51 & Discharged with recovery \\
\hline
\end{tabular}


bial proliferation. However, these products lack the epithelial layer, and in most cases, the use of such products will generally be followed by the inoculation of the split-thickness skin autograft for permanent coverage in a two-step procedure. We applied a split-thickness skin autograft after a mean of $2 \mathrm{l} .4$ days from the application of $\mathrm{Nevelia}^{\circledR}$.

In severe burns, various options are available after the clinicians perform early escharotomy. These options include allograft usage, DS, keratinocyte autoculture or antimicrobial dressing material application. Allograft usage may pose problems because of rejection and infection. Antimicrobial dressing material application generally does not provide the patient with enough protection from bacteraemia. Keratinocyte autoculture has not progressed to qualify for routine clinical usage.

Identifying a successful material that will be helpful during the eschar management period is very important. In recent years, DS has played important roles in burn treatment protocols. After escharotomy, an effective DS is very helpful in building a protection cover for the body. If DS is effective, then, the survival percentage of the patient increases.

There is still a possibility of harvest morbidity that may be inadequate in donor sites in wide burn areas. As indicated in the literature, ${ }^{[1]]}$ the use of $\mathrm{Nevelia}^{\circledR}$ allows us to harvest thinner split-thickness skin autografts and thus donor sites heal faster. These materials are also helpful in improving the elasticity of the skin after split-thickness skin graft application.

Despite the potential and need for DS, further research is required to strengthen the scientific evidence of the potential impacts and to develop new technologies and products. ${ }^{[2,13]}$ However, these substitutes have significant limitations when used in the presence of infections or full-thickness defects. ${ }^{[14]}$ In our case series, integration failed only in two of the 20 cases. These two cases had burn wound in $92 \%$ and $96 \%$ of their TBSA and had many comorbidities. Their clinical status was critical, and they died from their injuries. Their wound healing was poor, probably due to multiorgan insufficiency.

DS appear as a key research strategy to improve sufficient scaffolds to obtain long-lasting and scarred artificial skin for stem cells, regenerative medicine applications and tissue engineering. ${ }^{[15,16]}$ Integra ${ }^{\circledR}$ Dermal Regeneration Template (Integra Life Science, NJ, USA) is a widely used for covering excised full-thickness burn wounds and has proven to be particularly valuable in patients with large burns and limited autograft donor sites. ${ }^{[1,17]}$ Integra ${ }^{\circledR}$ consists of the following two layers: a DS made of porous bovine collagen and chondroitin-6sulfate glycosaminoglycan and an epidermal substitute made of a synthetic silicone polymer. The dermal layer serves as a matrix for infiltration by fibroblasts and other cells from the wound bed. De Angelis B et al. reported that Nevelia ${ }^{\circledR}$ had early regenerative properties in epidermal proliferation and dermal regeneration when compared with that of Integra. The study also showed that Nevelia ${ }^{\circledR}$ revealed more pronounced angiogenesis against Integra ${ }^{\circledR}$, which was evaluated with $\alpha$-SMA immunohistochemistry. ${ }^{[10]}$ In the present study, we found good integration and wound healing process with Nevelia ${ }^{\circledR}$.

\section{Conclusion}

The findings of the present study provide favourable results of incorporating $\mathrm{Nevelia}{ }^{\circledR}$ in our daily practice for the treatment of severely burned patients. Authors conclude that $\mathrm{Nevelia}^{\circledR}$ is safe as well as easy to use. Additionally, graft loss over Nevelia ${ }^{\circledR}$ is unusual.

Conflict of interest: None declared.

\section{REFERENCES}

1. Lee KH. Tissue-engineered human living skin substitutes: development and clinical application. Yonsei Med J 2000;41:774-9. [CrossRef]

2. Pham C, Greenwood J, Cleland H, Woodruff P, Maddern G. Bioengineered skin substitutes for the management of burns: a systematic review. Burns 2007;33:946-57. [CrossRef]

3. van der Veen VC, van der Wal MB, van Leeuwen MC, Ulrich MM, Middelkoop E. Biological background of dermal substitutes. Burns 2010;36:305-21. [CrossRef]

4. Hodgkinson T, Bayat A. Dermal substitute-assisted healing: enhancing stem cell therapy with novel biomaterial design. Arch Dermatol Res 2011;303:301-15. [CrossRef]

5. Lund CC, Browder NC. The estimation of areas of burns. Surg Gynecol Obstet 1944;79:352-8.

6. Oravcová D, Koller J. Currently available skin substitutes. Cas Lek Cesk 2014;153:7-12.

7. Supp DM, Boyce ST. Engineered skin substitutes: practices and potentials. Clin Dermatol 2005;23:403-12. [CrossRef]

8. Shevchenko RV, James SL, James SE. A review of tissue-engineered skin bioconstructs available for skin reconstruction. J R Soc Interface 2010;7:229-58. [CrossRef]

9. Hansbrough JF, Franco ES. Skin replacements. Clin Plast Surg 1998;25:407-23.

10. De Angelis B, Orlandi F, Fernandes Lopes Morais D'Autilio M, Scioli MG, Orlandi A, Cervelli V, et al. Long-term follow-up comparison of two different bi-layer dermal substitutes in tissue regeneration: Clinical outcomes and histological findings. Int Wound J 2018;15:695-706.

11. Heimbach D, Luterman A, Burke J, Cram A, Herndon D, Hunt J, et al. Artificial dermis for major burns. A multi-center randomized clinical trial. Ann Surg 1988;208:313-20. [CrossRef]

12. Shahrokhi S, Arno A, Jeschke MG. The use of dermal substitutes in burn surgery: acute phase. Wound Repair Regen 2014;22:14-22. [CrossRef]

13. Philandrianos C, Andrac-Meyer L, Mordon S, Feuerstein JM, Sabatier F, Veran J, et al. Comparison of five dermal substitutes in full-thickness skin wound healing in a porcine model. Burns 2012;38:820-9. [CrossRef]

14. McGuigan FX. Skin substitutes as alternatives to autografting in a wartime trauma setting. J Am Acad Orthop Surg 2006;14(10 Spec No.):S87-9. [CrossRef]

15. Bloemen MC, van Leeuwen MC, van Vucht NE, van Zuijlen PP, Middelkoop E. Dermal substitution in acute burns and reconstructive surgery: a 12-year follow-up. Plast Reconstr Surg 2010;125:1450-9. [CrossRef] 
16. Ziegler UE, Debus ES, Keller HP, Thiede A. Skin substitutes in chronic wounds. [Article in German]. Zentralbl Chir 2001;126 Suppl 1:71-4.

17. Heimbach DM, Warden GD, Luterman A, Jordan MH, Ozobia N,
Ryan CM, et al. Multicenter postapproval clinical trial of Integra dermal regeneration template for burn treatment. J Burn Care Rehabil 2003;24:42-8. [CrossRef]

\section{OLGU SERISİ - ÖZET}

\section{Ağır yanık hastalarının tedavisinde deri eşdeğeri Nevelia ${ }^{\circledR}$ deneyimimiz \\ Dr. Hakan Yiğitbaş, ${ }^{1}$ Dr. Erkan Yavuz, ${ }^{1}$ Dr. Evrim Beken Özdemir, ${ }^{1}$ Dr. Önder Önen, ${ }^{1}$ \\ Dr. Halime Hanım Pençe, ${ }^{2}$ Dr. Serhat Meriç, ${ }^{1}$ Dr. Atilla Çelik, ${ }^{1}$ Dr. Fatih Çelebi, ${ }^{1}$ \\ Dr. Ahmet Çınar Yastı, ${ }^{3}$ Dr. Tansel Sapmaz, ${ }^{4}$ Dr. Aydın Zilan, ${ }^{1}$ Dr. Mustafa Turan ${ }^{1}$}

${ }^{1}$ Sağlık Bilimleri Üniversitesi Bağcılar Eğitim ve Araştırma Hastanesi, Genel Cerrahi Kliniği, İstanbul

${ }^{2}$ Sağlık Bilimleri Üniversitesi Tıp Fakültesi, Biyokimya Anabilim Dalı, İstanbul

${ }^{3}$ Sağılı Bilimleri Üniversitesi Ankara Numune Eğitim ve Araştırma Hastanesi, Genel Cerrahi Kliniği, Ankara

${ }^{4}$ Sağlık Bilimleri Üniversitesi Tıp Fakültesi, Histoloji ve Embriyoloji Anabilim Dalı, İstanbul

AMAÇ: Bu araştırma, ağır yanık hastalarının tedavisinde deri eşdeğeri, Nevelia ${ }^{\circledR}$ ’ın etkinliğini ve güvenliğini geriye dönük olarak değerlendirmeyi amaçlamaktadır.

GEREÇ VE YÖNTEM: Mayıs 20।7-Mayıs 2018 tarihleri arasında çalışmamıza 20 ağır yanıklı hasta alındı. Eskarektomiden sonra yara tedavi protokolü iki aşamalı bir prosedürle uygulandı. Deri eşdeğeri implantasyonunu kısmi kalınlıkta deri grefti takip etti. Ameliyat ihtiyacı, komplikasyonlar, hastanede kalış süresi ve genel sağkalım analiz edildi.

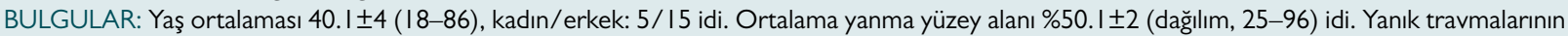
ve yandaş hastalıklarının ciddiyeti nedeniyle iki hasta kaybedildi. Olgularda greft, Nevelia ${ }^{\circledR ’}$ uygulamasından ortalama 21.2 gün sonra yapıldı. Nevelia ${ }^{\circledR}$ kaynaklı herhangi bir komplikasyon gelişmedi. Hastalar ortalama $55.2 \pm 4$ günde taburcu edildi.

TARTıŞMA: Bu çalışma Nevelia ${ }^{\circledR}$ 'nın düşük komplikasyon oranları ve kısa hastanede yatış süresi ile ağır yanık hastalarında güvenli ve etkili bir şekilde kullanılabileceğini göstermiştir.

Anahtar sözcükler: Ağır yanık; eskar yönetimi; deri eşdeğeri.

Ulus Travma Acil Cerrahi Derg 2019;25(5):520-526 doi: 10.14744/tjtes.2019.24358 